\title{
Ontronding in wit en bruin Afrikaans'
}

\begin{abstract}
The aim of this presentation is firstly to describe the phenomenon of delabialization of abnormal front vowels in Afrikaans, concentrating on the language of a few white and brown native speakers, and secondly to shed some light on the theoretical implications of the findings. The temporal characteristics of the vowels in three separate reading tasks and the extent to which the language users are able to distingwish the intended rounded vs. unrounded vowels and diphthongs correctly in a perception experiment are central considerations. With the results of the experiments in mind, the focus will fall on whether there can be consideration of absolute neutralization of the opposition rounded : unrounded for these vowels and diphthongs. Finally, the results will be evaluated in the light of the lively debate that currently exists on the question of the possibility of absolute neutralization.
\end{abstract}

\section{Inleiding}

Die doel van hierdie bydrae is eerstens om 'n beskrywing te gee van die verskynsel van ontronding van die abnormale voorvokale in die Afrikaans van enkele wit en bruin moedertaalsprekers, en tweedens om die teoretiese implikasies van die bevindinge uit te lig. Daar sal in 'n produksietoets gekonsentreer word op die temporele eienskappe van die vokale in drie leesopdragte, en in 'n persepsietoets op die mate waarin Afrikaanssprekende luisteraars die bedoelde geronde respektiewelik ongeronde vokale en diftonge, soos dit deur hierdie sprekers gelees is, korrek kon identifiseer. In hierdie eksperiment word hierdie mate waarin die luisteraars die bedoelde uitspraak van die lesers korrek kon vasstel,

1 Geldelike bystand gelewer deur die Sentrum vir Wetenskapsontwikkeling vir hierdic navorsing word hiermec crken. Menings uitgespreck en gevolgtrckkıngs waartoe geraak is, is diè van die outeur, en moet nic noodwendig aan die Sentrum vir Wetenskapsontwikkeling tocgeskryf word nic. 
gelykgestel aan die wyse waarop die sprekers die betrokke klanke wel as gerond of ongerond uitgespreek het. Dit is natuurlik moontlik dat die luisteraars foute kon maak, maar in die lig van die belangrikheid van dié dekodeerders in die kommunikasieproses, is hulle oordeel wel belangrik. Daar is tot op hede geen plaasvervanger vir hierdie oordeel nie.

Daar sal met die resultate van die eksperimente in gedagte gekyk word of daar sprake is van absolute neutralisasie van die opposisie gerond : ongerond by hierdie vokale en diftonge. Ten slotte sal die resultate geëvalueer word ten opsigte van die lewendige debat wat daar tans bestaan met betrekking tot die vraag of absolute neutralisasie wel moontlik is.

\section{Die verskynsel van ontronding in Afrikaans}

Ontronding is 'n duidelike kenmerk van gesproke Afrikaans en dit wil voorkom asof dit besig is om veld te wen. Hierdie waarneming vind neerslag in 'n hele aantal beskrywings van Afrikaans en sy variëteite.

Die term ontronding is eintlik onvanpas, omdat daar in Afrikaans - selfs in gevalle waar die vokaal as 'gerond' bedoel en waargeneem kan word - weinig sprake is van 'n gerondheid van die lippe by uitspraak, of selfs van 'n saamtrek van die mondhoeke (vgl. Wissing, 1982). Van Wyk (1977) noem die uitspraak van die abnormale voorvokale substituutronding. Vir die doel van hierdie artikel word hierdie verskynsel egter steeds ontronding genoem.

Ontronding van die abnormale voorvokale (geskrewe $u u$, $e u$ en $u$ en geronde diftonge $u i$, soos in resp. nuus, neus, rus en duif) is 'n bekende, ou en wydverspreide verskynsel in Afrikaans, en een van die markante, hoewel nie unieke nie, eienskappe in vergelyking met Nederlands. Dit is reeds vir Oudnederlands opgeteken. Van Bree (1987:134) noem gevalle soos crepel (vir kreupel) en evel (vir euvel). Ponelis (1990/1) haal verskeie gevalle uit (geskrewe) agtiende-eeuse Afrikaans aan (bv. brig (brug), hilp (hulp), en vier (vuur)). Kotzé (1984) vind ontronding ook in verskeie historiese bronne. De Villiers en Ponelis (1987:1023 ) is van mening dat die abnormale voorvokale nog dialekties en by ouer mense voorkom, maar dat dit veral in die stede net in goedversorgde en selfs deftige taalgebruik gehoor word. Hulle noem die afwesigheid van ontronding "merkers van standaarduitspraak". Die geldigheid hiervan sal in dié bydrae getoets word. Volgens De Villiers en Ponelis (1987) is die ontronding van die geronde voorvokale in sowel die koine- as Kaapse Vernakular-Afrikaans al 'n voldonge feit. Daarenteen het Raubenheimer (1994) bevind dat daar 'n statisties hoogs betekenisvolle verskil $(p=0,00001)$ is tussen die abnormale geronde voorvokale en die diftong [œy] en hulle ongeronde maats toe dit deur 'n groep sprekers van 
Standaardafrikaans (dosente) uitgespreek is in verskillende leestake (sinne, drasinne en woordpare).

Klopper (1983) noem die ander kant hiervan, dit wil sê dat ontronding (spesifiek van $u i$ in Kaapse Afrikaans) "gestigmatiseerd" is (p. 88). De Villiers en Ponelis (1987) maak 'n ander toepaslike opmerking, naamlik dat hiperkorreksie waargeneem kan word in gevalle waar 'n formeler toon ingeslaan word. Deur sodanige hiperkorreksie word normale ongeronde vokale (soos die vokaal in pit) gerond (dus as [œ]) uitgespreek. Kotzé (1984) meld die hiperkorrekte oorronding van die vokale $/ y /$ en $/ ø /$, en die diftong /œi/ in formele style. Hiperkorreksie van enige aard is gewoonlik 'n aanduiding van 'n onstabiele toestand.

Van Wyk (1983:167) is van mening dat die geronde voorvokale in gepidginiseerde Afrikaans, soos in sogenaamde Swartafrikaans, heeltemal ontrond word. Eie waarneming bevestig dit grotendeels - geronde voorvokale kom uiters selde voor, selfs in die uitspraak van hoogs gesofistikeerde swart sprekers van Afrikaans. Volgens De Wet (1993:179) word die geronde voorvokale van Afrikaans eerder vervang deur ander vokale wat uit die swart spreker se eie taal afkomstig is; volgens De Wet se voorbeelde, nie altyd met die ongeronde teëhangers nie (vgl. gadêldag (geduldig) en skêldag (skuldig), teenoor mier (muur) en hys (huis), vgl. ook Meiring \& Retief, 1991:30).

Die indruk wat die Afrikaans van die Noordweste van die land laat - die gebied waar die empiriese ondersoek gedoen is, is dat daar wel op groot skaal ontrond word. In hoeverre gesê kan word dat dit volledig is, is egter 'n vraag. Daar word dikwels van die Afrikaans van bruin sprekers gesê dat die proses van ontronding in hulle taalgebruik volkome is. Dit is moontlik ' $n$ oorveralgemening, wat betref die geografiese herkoms van die sprekers én die bevolkingsgroep waartoe die sprekers behoort. Die sprekers van Kharkam in Namakwaland gebruik, aan die ander kant, volgens Links (1989) duidelik geronde abnormale voorvokale, en ontronding is afwesig in hulle uitspraak. Die diftong ontrond ook nie, alhoewel dit monoftongeer tot $[y(:)]$. Links veralgemeen (wel versigtig) na die ander streke in Namakwaland toe. ${ }^{2}$

Uit voorgaande kort oorsig blyk dit dat ontronding in Afrikaans 'n baie algemene verskynsel is. Die aard en veral die omstandighede en die volledigheid waarin dit voorkom, is egter minder duidelik. Dit wil met die eerste oogopslag voorkom asof ontronding gevoelig is vir die herkoms (in die verskillende betekenisse van

2 Hicrdic uitspraak oor Namakwalands sal waarskynlik juister wees indien dit stel dat ontronding nie algemeen is nie, of dat die geronde uitspraak baie algemeen is. Ek grond hicrdic mening slegs op 'n radio-uitsending, waarin 'n tipiesc Namakwalander, mnr. Japie Louw aan die woord is. 
die woord) asook die gesprekskonteks. Gevolglik is daar in hierdie ondersoek van sowel wit as bruin jong moedertaalsprekers van Afrikaans gebruik gemaak. Aangesiell die betrokke klanke onder eksperimentele omstandighede geproduseer is, sou die styl as formeel getipeer kon word. Soos hierbo uitgewys is, kom geronde uitspraak van die abnormale voorvokale waarskynlik slegs in formele styl voor. Daar sou wel sprake van egte neutralisering kon wees indien een of albei groepe proefpersone - wat produksie betref - nie 'n onderskeid maak tussen die ongeronde voorvokale (en die genoemde diftong) en hulle geronde paarmaats nie, selfs onder sodanige eksperimentele omstandighede, wat uit die aard van die saak as onnatuurlik en formeel getipeer moet word. Daar moet egter ook persepsietoetse uitgevoer word om te kan vasstel hoe die hoorder hierdie produksie ervaar. In geval van 'n moontlike produksiematige volledige neutralisasie sou die hoorder natuurlik ook geen verskil kan waarneem nie. ${ }^{3}$

\section{Die teoretiese belang van ontronding in Afrikaans}

In gevalle waar opposisies tussen twee foneme opgehef word, is dit natuurlik nie meer nodig om albei as onderliggende segmente in die teoretiese beskrywing van die betrokke taal te poneer nie. Een so 'n geval in Afrikaans is die opheffing van die onderskeid tussen $\mathrm{Ndl}$. / f/ en / $/ \mathrm{v}$ (geskrewe $f$ en $v$ ): die aanvangskonsonante van die woorde vier en fier word albei deur onderliggende /f/ in Afrikaans weergegee. Die vraag analoog hieraan is dus of die genoemde ontronding so ver gevorder het dat die opposisie tussen die geronde respektiewelik ongeronde diftonge en voorvokale (bv. /y/ en /i) sodanig volledig opgehef word dat slegs een vokaal (bv. /i/) as onderliggende segment aangeneem kan word. In so 'n geval sal die onderliggende vorme van sowel muur as mier dan $/ \mathrm{mi}: \mathrm{r} /$ wees.

Hierdie kwessie hang, soos reeds uitgewys, saam met die vraag of hier wel sprake van absolute of dan volledige neutralisasie is. Navorsing met betrekking tot die moontlike neutralisasie van die stemhebbend: stemloos-kontras aan sillabeen woordeinde in ' $n$ hele aantal tale het getoon dat die produksie (uitspraak) daarvan nie volledig is nie, byvoorbeeld in Duits (Port et al., 1981; Port \& O’Dell, 1985; Port et al., 1989), in Katalaans (Dinnsen \& Charles-Luce, 1984; Charles-Luce \& Dinnsen, 1987, Charles-Luce, 1993); in Pools (Slowiaczek \& Dinnsen, 1985) en ook in Afrikaans (Wissing \& Van Rooy, 1992). Hierdie standpunt word wel deur ' $n$ aantal navorsers bevraagteken, byvoorbeeld deur Fourakis en Iverson (1984) in die geval van Duits, en Jassem en Richter (1989) met betrekking tot Pools. Charles-Luce (1993) se navorsing toon ook dat hierdie

3 Dit is egter ook baie waarskynlik dat die temporele cienskappe van die betrokke segmente nie dic enigste faktor by ontronding is nie Die spektralc cienskappe sou ewencens 'n belangrike rol speel. Dit word egter in 'n ander ondersoek gedoen 
neutralisasie slegs volledig is wanneer die betekenis van die woord waarin die betrokke klanke voorkom kontekstueel duidelik is. Konteks sal dus ook sover moontlik gekontroleer moet word.

In die volgende afdeling word meer inligting aangaande die eksperimentele ondersoek verskaf.

\section{Die empiriese ondersoek}

Twee eksperimente is uitgevoer: 'n produksie- en 'n persepsie-eksperiment. In eersgenoemde is die uitspraak van 'n aantal proefpersone op band opgeneem en deur middel van 'n gerekenariseerde spraakanalisesisteem ten opsigte van die temporele eienskappe van die vokaal- en diftongsegmente (dit wil sê die lengte van dié segmente) van die fokuswoorde geanaliseer, en in laasgenoemde is nagegaan in hoe 'n mate die woorde waarin dié segmente voorkom, korrek deur 'n groep luisteraars gedekodeer word.

\subsection{Die produksie-eksperiment}

\subsubsection{Die proefpersone}

Twee wit en twee bruin sprekers van Afrikaans (resp. twee vroulike, en 'n vroulike en manlike student van die $\mathrm{PU}$ vir $\mathrm{CHO}$ ) het op 'n vrywillige basis aan die produksiegedeelte van die eksperiment deelgeneem. Hulle is streng gesproke nie op 'n willekeurige wyse uitgekies nie, maar ook nie spesifiek op grond van hulle uitspraak genader om aan die eksperiment deel te neem nie. Almal is uit die noordwestelike gedeelte van die land afkomstig, en hulle uitspraak kan, impressionisties geoordeel, as tipies van die streek getipeer word. Dit is in eksperimente van hierdie aard baie algemeen om slegs van enkele sprekers gebruik te maak. Eefting (1991) het, om een tipiese voorbeeld te noem, slegs een proefpersoon gebruik. Die proefpersone van die huidige ondersoek was almal ongeveer 20 jaar oud.

\subsubsection{Die stimulusmateriaal}

Die fokuswoorde is in drie leestake gebruik: 1. natuurlike sinne (sinne), 2. metalinguistiese sinne (drasinne) en 3 . woordpare. Die fokuswoorde het bestaan uit vyf pare, waarvan een lid 'n abnormale voorvokaal/geronde diftong en een die ongeronde teëhanger daarvan was (dus - dis, geus - gees, steun - steen, nuus - 
$n^{n} s^{4}$, en fulf-vyf). Van hierdie woorde kan die woorde fuif en geus as vreemd getipeer word, omdat dit woorde is wat selde in Afrikaans gebruik word. In 'n opname onder 20 akademici is die gebruiksfrekwensie van die woorde fuif en geus op 'n vyfpuntskaal (waar 1 = baie bekend, en 5 = baie onbekend) tussen 4 en 5 geplaas, teenoor die woorde gees en vyf, wat op 1 geplaas is. Dit kan aanvaar word dat die ander ses woorde ook eerder bekend as onbekend sal wees.

Elke woord is ewe veel kere in elkeen van die drie leestake gebruik. Die sinne is so gekonstrueer dat die kem van die fokuswoorde nie deur enige van die bekende faktore aan duurtewisseling onderhewig is nie (vgl. Raubenheimer, 1994 vir 'n volledige bespreking van al hierdie faktore). Die posisie in die sin, die klemtoon wat die betrokke woord ontvang en die fonetiese konteks is dus gekontroleer. Die lede van die woordpare in hierdie leestaak is ook sover moontlik van mekaar geskei. Die bedoeling hiervan was dat die lesers nie moes agterkom dat lede van 'n paar (bv. nuus en nies) met mekaar gekontrasteer word nie. Die sinne is eers drie maal gelees voordat na die volgende leestaak (drasinne) oorgegaan is. Sinne soos Die steun van die publiek vir hom het afgeneem, en Geen steen sal onaangeroerd gelaat word nie is gebruik, en is deur ongeveer twaalf ander sinne uitmekaar gehou. Sodoende is gepoog om vir die proefpersone die feit te verdoesel dat dit in die eksperiment om 'n kontras tussen sulke pare woorde gegaan het (dit is na afloop van die leessessie by navraag bevestig).

Dieselfde woorde is in die drasinne (carrier sentences) voorgelees (ook drie keer). Hierdie sinne het aan dieselfde voorwaardes as die sinne voldoen, maar is kunsmatig in dié sin dat die fokuswoord in kort sinne van die tipe $A$ het .... geX (bv. Barend het nuus geskryf) ingebed is (waar $\mathbf{A}$ 'n persoonsnaam is, bv. Barend, en X'n werkwoord, bv. spel of skryf). Daar is 25 verskillende eiename aan die begin van elke sin gebruik, asook vier verskillende werkwoorde, waarmee gepoog is om die proefpersone onder die indruk te laat dat dit eerder om daardie woorde as om die ingebeddes gaan. Nogtans was die moontlikheid groter as in die geval van die eerste leestaak (sinne) dat die lesers sou kon begin agterkom dat die fokus op die betrokke fokuswoorde was, en, meer in besonder, dat dit om die kontras tussen die lede van die onderskeie woordpare gegaan het. In so 'n geval sou hulle moontlik meer aandag aan die geronde uitspraak van die vokale / diftong gee, en dus ook 'n groter verskil daartussen maak.

Die woorde is laastens in een lang sin gebruik: "Die woorde dis en dus en gees en geus ...(ens.) ... is almal Afrikaanse woorde". Die lede van die pare is dus langs mekaar geplaas met die bedoeling dat die lesers, sekerlik in die tweede en

4 Hoewel sowel [y] as [i] foneties kort is, word hulle soms, soos in die geval van Nederlands as fonologies lank gcklassifiscer. 
lesing daarvan, bewus daarvan moes word dat dit om ' $n$ vergelyking tussen die lede van die woordpare gegaan het. Dit kan dus verwag word dat hulle ' $n$ duidelike kontras moes maak indien dit in hulle taalsisteem bestaan.

Omdat dit om segmentlengtes gaan, is die woorde nie fisies in pare aangebied nie, dus nie:

$$
\begin{aligned}
& d i s-d u s \\
& v y f-f u i f
\end{aligned}
$$

nie, omdat dit moeilik is vir ' $\mathrm{n}$ leser om albei lede teen dieselfde tempo en intonasie te lees: die laaste lid van so 'n paar word dikwels met 'n dalende toon, en gevolglik ietwat gerek gelees, wat natuurlik ongewens is wanneer dit om segmentlengtes gaan.

\subsubsection{Afneem- en nasienprosedures, en statistiese verwerking}

Die bandopnames is in 'n klankdigte ateljee gemaak. Hoëkwaliteitapparaat is gebruik. Die proefpersone is gevra om die drie stelle leesmateriaal (sinne, drasinne en woordpare) so natuurlik moontlik en teen 'n gemaklike tempo in die kassetband in te lees, en wel, soos reeds gemeld, drie keer elk.

Die opnames is deur middel van die Computerized Speech Laboratory (CSL) van Kay Elemetrics versyfer, en wel teen 'n monsterfrekwensie van $20 \mathrm{kHz}$. Die klankgolfvorme en die daarmee gesinchroniseerde spektrogramme is daarna op ' $n$ rekenaarskerm vertoon, waarna segmentering uitgevoer is en die lengtes van die vokale en diftonge vasgestel is. Die standaardkriteria vir klankgolfvorm- (vgl. Repp \& Williams, 1985) en spektrogramsegmentering (bv. O'Shaughnessy, 1981 ) is hiervoor gebruik. Segmentduurtes is vir latere statistiese bewerking opgeteken. Afgesien van gewone beskrywende statistiek (gemiddeldes, frekwensies ens.) is variansie- en diskriminantontledings gedoen.

\subsection{Die persepsie-eksperiment}

\subsubsection{Die proefpersone}

Vyf en twintig eerstejaarstudente, waarvan die moedertaal Afrikaans is, het aan die luistertoets deelgeneem. Geeneen het enige gehoorprobleme gerapporteer nie.

\subsubsection{Die stimulusmateriaal}

Die voorlesings van die vier proefpersone wat in 4.1.1 gemeld is, is in 'n geredigeerde vorm as stimulusmateriaal vir hierdie toets gebruik, en wel die tweede en derde leesgedeeltes, dit wil sê die drasinne en die woordparesin. 'n Aantal 
drasinne van elk van die vier proefpersone is eerstens deur middel van die CSLredigeerder geïsoleer, waarna ' $n$ verteenwoordigende aantal woorde met bedoelde, onderliggend (geskrewe vir dié doeleindes) geronde en ongeronde (dus nie ontronde nie) vokale en diftonge rekenaarmatig uitgeknip en in 'n drasin ingeplak is. Sodoende is ' $n$ aantal drasinne van die tipe Barend het steen gesê, Barend het vyf gesê ensovoorts gevorm. Hierdie sinne is in so 'n orde op band van die CSL af oorgedra dat verwante woorde (soos steen en steun), nie direk langs mekaar te staan gekom het nie. Gemaklike pouses is tussen die sinne gehandhaaf. Tweedens is 'n aantal woordpare uit die lesers se woordpaarsinne geknip, en ook, op dieselfde wyse op band oorgedra. Hier is dus pare soos fuif en vyf of nuus en nies, in hierdie vorm, bymekaar gemaak. Hierdie bandopnames is in die luistereksperiment as stimulusmateriaal gebruik.

\subsubsection{Afneem- en nasienprosedures, en statistiese verwerking}

Die drasinne is twee keer aan die luisteraars voorgespeel: die eerste keer (Taak 1) moes hulle op 'n leë vel papier, dus sonder enige geskrewe hulp, neerskryf om watter woord dit gegaan het (spesifiek: in 'n sin soos Barend het fuif gesê, moes die woord fuif neergeskryf word). In Taak 2 is dieselfde sinne voorgespeel, maar hierdie keer is die twee moontlikhede op 'n antwoordvel verskaf, en die luisteraars moes die woord merk wat hulle gemeen het gesê is. In Taak 3 is die woordpare voorgespeel, en die opdrag was om albei woorde in die volgorde waarin dit gehoor is, op 'n leë vel papier, dus ook sonder skriftelike hulp, neer te skryf. Hier is aan die deelnemers gesê dat albei woorde dieselfde kon wees, anders sou hulle telkens die tweede woord as verskillend van die eerste aanvaar het, sodat daar ' $n$ vooroordeel sou ontstaan.

Die drie take is vervolgens nagesien ten opsigte van die parameters bedoelde vokaalidiftong (m.n. rond of nie-rond), en respons van die deelnemer (ook in terme van rond of nie-rond). Die data is daarna statisties ontleed (hiervoor is die pakket CSS van Statsoft Inc. gebruik).

\section{Resultate}

Die resultate van die produksietoets sal eers gegee word, en daarna dié van die persepsietoetse. In die produksietoets is die lengtes van al die segmente, gerond en ongerond, van een wit en een bruin spreker (willekeurig gekies) gebruik. Daar is geen goeie rede waarom hulle nie as verteenwoordigend van die ander twee, en selfs van die spraakgroepe as geheel geneem kan word nie, alhoewel dit natuurlik ook nie bewys kan word dat dit wel die geval is nie. Dit is egter tipies ' $n$ probleem van alle empiriese ondersoeke van hierdie aard. Eefting (1991) het byvoorbeeld, soos vroeër gemeld, slegs een proefpersoon, op grond van die feit dat 
hy ' $\mathrm{n}$ bekende radio-omroeper was, as verteenwoordigend van alle Nederlandssprekendes geneem.

\subsection{Die resultate van die produksietoets}

Die gemiddelde lengtes van die ronde segmente (al drie die take gesamentlik; al twee die proefpersone) is $101 \mathrm{~ms}$, en dié van die ongerondes $92 \mathrm{~ms}$. Dit is $\mathrm{n}$ verskil van 10 persent. Die p-waarde is 0,072 , wat nie betekenisvol is as die 0,05 -vlak as betekenisvol aanvaar word nie (vergelyk hiervoor Fig. 1):

Figuur 1: Vergelyking van die lengtes van die geronde en ongeronde vokale/ diftonge van albei die proefpersone $(\mathrm{N}=180)$. Lengtes op die $\mathrm{Y}$-as word in millisekondes (ms) gegee.

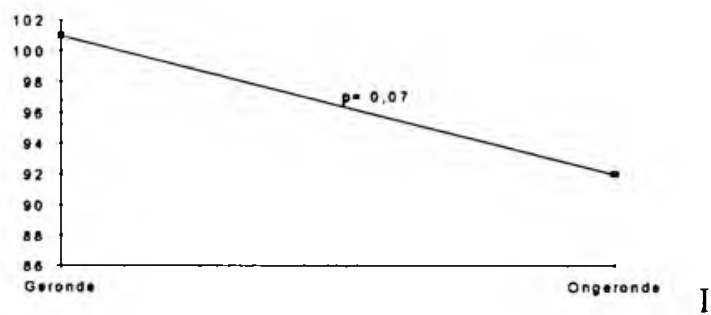

In Figuur 2 word die data van die twee sprekers afsonderlik gegee, dog steeds van al drie take gesamentlik. In Figuur 3, 4 en 5 word dit per taak gedoen.

Figuur 2: Vergelyking tussen ' $n$ bruin en ' $n$ wit proefpersoon se lengtes van die onderliggend geronde en ongeronde segmente in al drie die leestake gesamentlik. $(\mathrm{N}=180)$

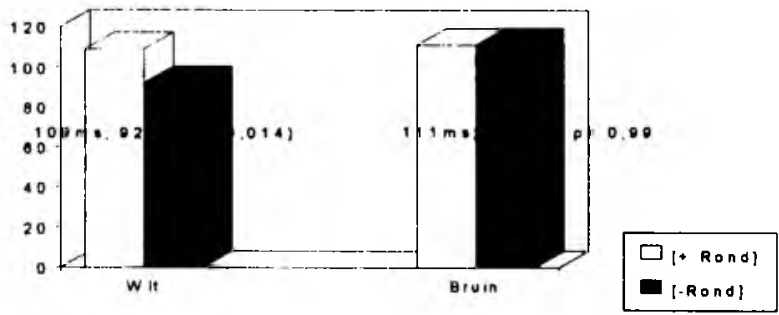


Figuur 3: Vergelyking tussen 'n bruin en 'n wit proefpersoon se lengtes van die onderliggend geronde en ongeronde segmente in die drie leestake afsonderlik.

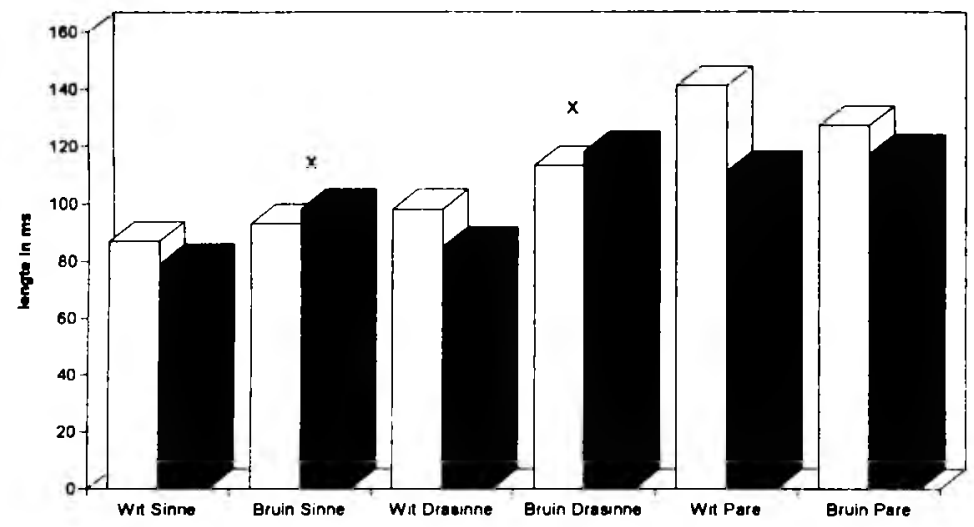

Slegs die verskille tussen die lengtes van geronde en ongeronde segmente van die wit spreker in die geval van die drasinne en die pare is statisties betekenisvol (resp. 0,05 en 0,008 ; of resp. $15 \%$ en $27 \%$ ). Let ook verder op die ongewone toestand dat die ongeronde segmente in twee gevalle by die bruin spreker (kyk aanduiding met die kruise) lánger (in plaas van die normale korter) as hulle geronde maats is (vgl. verder die bespreking in 6). Vergelyk verder Tabel 1, waarin die omgekeerde waardes in terme van negatiewe persentasies uitgedruk word:

Tabel 1: Segmentlengtes van Figuur 3 (in ms). $\mathrm{N}=180$

\begin{tabular}{|c|c|c|c|c|c|c|}
\hline \multirow[t]{2}{*}{ Lengtes: } & \multicolumn{2}{|c|}{ In sinne } & \multicolumn{2}{|c|}{ In drasinne } & \multicolumn{2}{|c|}{ In pare } \\
\hline & Wit & Bruin & Wit & Bruin & Wit & Bruin \\
\hline [+Rond] & 87 & 93 & 98 & 113 & 141 & 127 \\
\hline [-Rond] & 79 & 98 & 85 & 118 & 111 & 117 \\
\hline$\%$ verskil & 10 & -5 & 15 & -4 & 27 & 9 \\
\hline
\end{tabular}


' $n$ Diskriminantanalise is vervolgens gedoen. Indien ' $n$ spreker ' $n$ absolute produksieverskil tussen geronde en ongeronde segmente sou maak, sou dit teoreties moontlik wees dat dié statistiese ontledingsmetode ook alle segmentwaardes (lengtes in hierdie geval) ondubbelsinnig sou toedeel aan die een of die ander kategorie (geronde resp. ongeronde segmente in dié geval). Daar sal dan in so 'n geval presies gediskrimineer kan word tussen die betrokke klasse waardes.

In Figuur 4 word die resultate van so 'n ontleding op die huidige gegewens weergegee:

Figuur 4: Diskriminantanalise van die produksiedata van die wit en bruin sprekers. $\mathrm{N}=180$

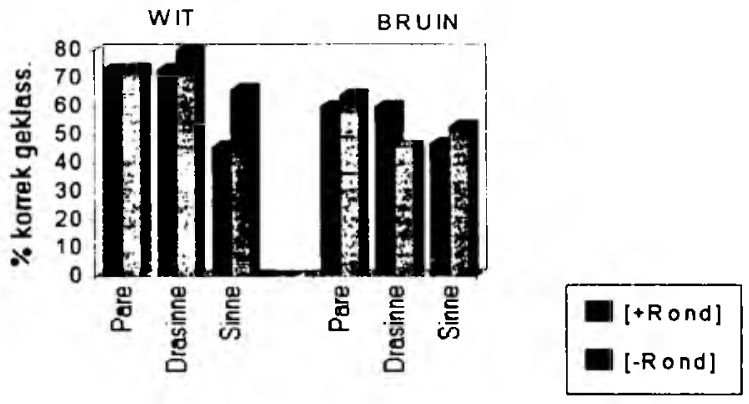

Hieruit wil dit voorkom asof die bedoelde geronde segment in die geval van die pare en die drasinne aanmerklik beter korrek geklassifiseer word in die geval van die wit spreker (resp. $73 \%$ en $73 \%$ teenoor $60 \%$ en $60 \%$ van die bruin spreker), terwyl dit ongeveer gelyk gebeur in die geval van die sinne ( $46 \%$ teenoor $47 \%$ ). Die wit spreker het in die geval van al drie take aanmerklik beter by die ongeronde segmente gevaar (resp. $73 \%, 80 \%$ en $66 \%$ (gem. $73 \%$ ), teenoor die bruin spreker se $64 \%, 46 \%$ en $53 \%$ (gem. $54 \%$ )).

Wat die segmentlengtes in die produksietoets betref, is daar, om saam te vat, wel betekenisvolle verskille in die geval van die wit spreker in twee van die drie leestake, maar geen in die geval van die bruin spreker nie. Sover dit die diskriminantanalise aangaan, lyk dit ook asof die wit spreker 'n groter onderskeid tussen geronde en ongeronde segmente maak, maar dit is 'n vraag of hierdie verskille sodanig is dat dit wel ook gereflekteer sal word in persepsietoetse, waar van die luisteraars verwag word om op grond van ouditiewe stimuli te oordeel of 'n klank gerond of ongerond is. Die resultate van hierdie ontledings gee ook nog nie uitsluitsel oor die vraag of die onderskeid tussen geronde en ongeronde segmente in die betrokke sprekers se taalsisteem opgehef is nie, met ander woorde, of die opposisie tussen die twee groepe onderliggend geneutraliseer is nie. Dit is moontlik dat die persepsietoets (5.2) meer lig hierop sal werp. 
Natuurlik is daar ook ander faktore, soos die spektraie eienskappe van die betrokke klanke wat 'n rol kan speel, maar daar word voorlopig nie hierop ingegaan nie. Die rol van temporele eienskappe sal eers in diepte bestudeer moet word.

\subsection{Die resultate van die persepsietoets}

In hierdie ontleding sal daar eers gekyk word na die resultate van al vier lesers, twee wit en twee bruin, en wel ten opsigte van al tien die woorde. Daar sal in die ontledings ook onderskei moet word tussen gebruiksfrekwensie / bekendheid van die eksperimentele woorde. Sodoende sal probeer word om vas te stel of ontronding gevoelig is vir die frekwensie of bekendheid van die woorde waarin dit voorkom, en indien wel, in hoe ' $n$ mate. Dit is moontlik dat neutralisasie eerder in veel gebruikte woorde voorkom, in welke geval daar nie veralgemeen kan word dat neutralisasie volkome is in 'n taal of variëteit van 'n taal nie.

\subsection{1 'n Ontleding van al vier die sprekers se uitspraak}

In hierdie afdeling word gekyk na die wyse waarop die uitspraak van die vier sprekers deur die deelnemers aan die persepsie-eksperiment gedekodeer word met betrekking tot die bedoelde gerondheid of nie van die stimuluswoorde.

Figuur 5: Die verdeling van al die response van die luisteraars (25) op die vier sprekers se uitspraak van die geronde en ongeronde woorde $(\mathrm{N}=2636)$ in al drie die herkenningstake (drasinne sonder geskrewe wenk; drasinne met wenk, en woordpare).

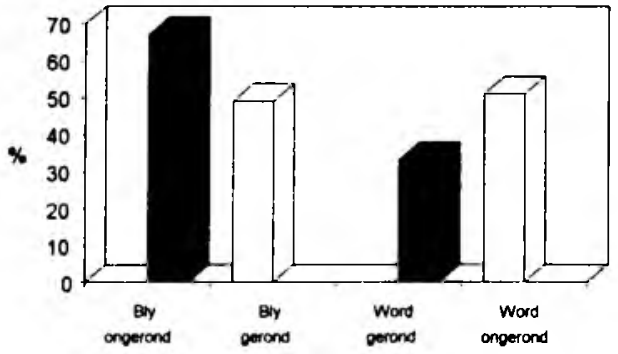

Uit hierdie gegewens blyk dit dat minder as die helfte (49\% of 616 gevalle) van die bedoelde geronde segmente as sodanig deur die luisteraars herken is. Daarenteen is $67 \%(\mathrm{~N}=934)$ van die bedoelde ongeronde segmente korrek geïdentifiseer. Bogenoemde dui duidelik op 'n oorwig ten gunste van die ongeronde klanke, en dus ook op ' $n$ sterk neiging in die rigting van 'n tendens van 'n ontrondingsproses in Afrikaans. Die hoë persentasie gevalle waarin bedoelde ongeronde klanke as 
gerond geklassifiseer is ( $33 \%$, of 454 gevalle), is oênskynlik teenstrydig hiermee, maar, as aangeneem word dat die klassifikasie van die luisteraars as betroubaar aanvaar kan word, kán dit onder andere dui op hiperkorrekte ronding van die kant van een of meer van die sprekers. Dit sal later weer bekyk word. Een en vyftig persent $(\mathrm{N}=632)$ van al die bedoelde geronde gevalle is inderdaad deur die luisteraars as ongerond geklassifiseer.

As hierdie resultate vergelyk word met die eksperiment met 'n 'professionele' spreker (wat 'n Superstandaardafrikaans praat) waama in die inleiding verwys is, is daar wel 'n groot verskil. In dié subeksperiment is hierdie spreker se uitspraak van 'n groep geronde en ongeronde vokale en diftonge soortgelyk aan dié van die hoofeksperiment op dieselfde wyse as wat hier beskryf is aan 'n groep volwasse Afrikaanssprekende persone (personeellede, akademies en nie-akademies, wat op 'n vrywillige basis deelgeneem het) voorgespeel. Slegs 'n klein persentasie gevalle ( $5 \%$ elk van die bedoelde geronde resp. ongeronde segmente) is deur hierdie proefpersone verkeerd geïdentifiseer - 'n gegewe wat op 'n baie stabiele uitspraak dui. Dit is natuurlik moontlik, en waarskynlik te verwagte, dat selfs hierdie spreker in informele spraak veel meer sal ontrond. Slegs op grond van hierdie kan egter gesê word dat daar weinig sprake van ontronding in Superstandaardafrikaans is.

Om terug te keer na die hoofondersoek: dit kan verwag kan word dat die sprekers in die derde leestaak, waarin die pare woorde (gerond vs. ongerond, soos bv. fuif vs. vyf) direk langs mekaar aangebied is, weens die deursigtigheid van die opset van die stimulusmateriaal ook meer aandag aan ronding sal gee en gevolglik veral minder sal ontrond. In Figuur 6 is daar dus net op die pareleestaak gekonsentreer, omdat dit 'n presieser aanduiding van die aard en omvang van ontronding by hierdie proefpersone behoort te gee. Die waardes vir geronde segmente wat ontrond word, en dié vir die ongerondes wat gerond word, word in die volgende figure nie gegee soos in Figuur 5 nie, omdat dit direk afgelei kan word van die gegewens wat wel in die figure opgeneem is.

Figuur 6: Soos in Figuur 5, maar net ten opsigte van die derde herkenningstaak (woordpare)

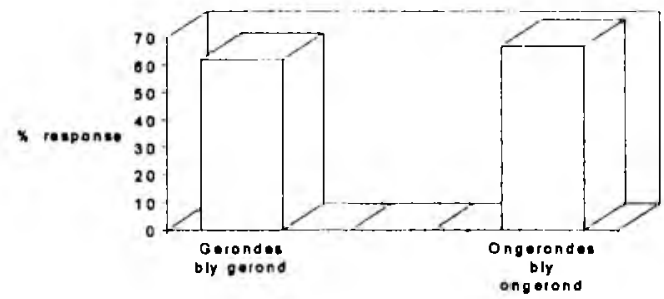


In vergelyking met Figuur 5 blyk dit dat die klassifikasie van die bedoelde ongeronde segmente prakties onveranderd bly (i.p.v. $67 \%$ ongeronde segmente wat as sodanig geklassifiseer is, is dit hier $68 \%$ ). Maar waar daar slegs $49 \%$ van die gevalle gerond gebly het, is dit hier nou $62 \%$. Dit is duidelik dat die aard van die aanbieding van die stimulusmateriaal en die opdrag ' $n$ rol speel by die mate van sukses in 'n herkenningstoets van hierdie aard. Dit wil dus lyk, op grond van hierdie resultate, asof ontronding in Afrikaans beduidend plaasvind, maar nog nie ' $n$ voldonge feit is nie.

In die volgende afdeling word die moontlikheid ondersoek dat ontronding moontlik verder gevorderd is in een van die twee taalvariëteite (die Afrikaans van die wit en die bruin sprekers).

\subsection{2 'n Ontleding van die twee taalvariëteite ten opsigte van ontronding}

Dieselfde ontleding as wat hierbo van die vier sprekers as groep gedoen is, word hier ten opsigte van die twee groepe uitgevoer. In Figuur 7 word die gegewens met betrekking tot al drie die herkenningstake gegee, en in Figuur 8 net vir die paretaak.

Figuur 7: Vergelyking van die twee groepe sprekers ten opsigte van die mate van segmentverandering in al drie die herkenningstake

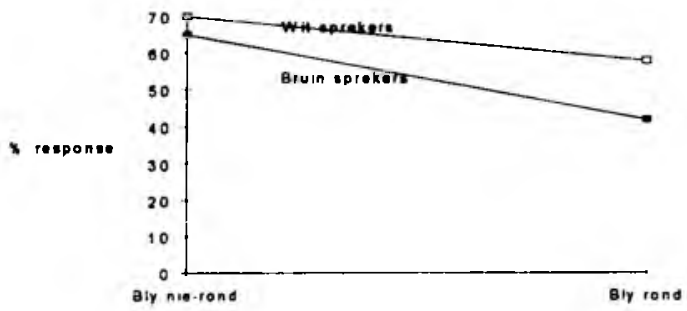

Hieruit blyk dat die twee groepe nie betekenisvol verskil ten opsigte van die mate waarin bedoelde ongeronde segmente as sodanig deur die luisteraars ervaar is nie, en gevolglik ook nie in die mate waarin (hiperkorrek?) gerond word nie. Daarenteen is daar wel ' $n$ statisties betekenisvolle verskil $(p=0,02)$ in die mate waarin bedoelde geronde segmente as sodanig geklassifiseer is (en dus in die mate waarin ontrond is). In albei gevalle het die wit spreker beter as die bruine gevaar. 
Figuur 8: Vergelyking van die twee groepe sprekers ten opsigte van die mate van segmentverandering in die woordpareleestaak

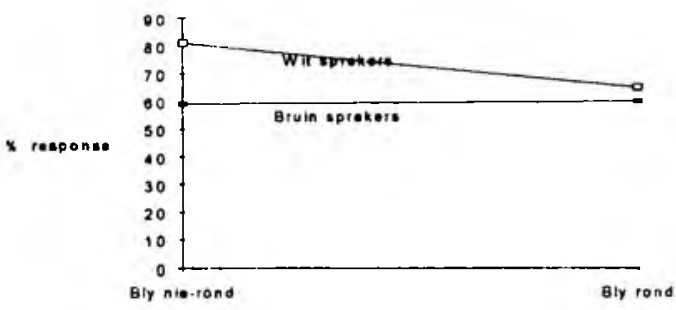

Die twee groepe sprekers verskil nie betekenisvol ten opsigte van ontronding soos in die geval van die drie herkenningstake gesamentlik (Fig. 7) nie, maar wel ten opsigte van Bly nie-rond, dus ook wat betref die mate waarin bedoelde ongeronde klanke (hiperkorrek?) as gerond uitgespreek is. Indien die vier sprekers afsonderlik bestudeer word, blyk dit dat een, 'n bruin spreker, betekenisvol meer hiervoor in die paretaak verantwoordelik is, en dat die ander drie ongeveer gelyk is. Die feit dat dit in al vier die gevalle veel meer gebeur as by die spreker van Superstandaardafrikaans, dui waarskynlik in die rigting van 'n algemene tendens tot ontronding in Afrikaans (kyk die verdere bespreking in 6).

Figuur 9: Vergelyking van die aantal kere wat die vier proefpersone se bedoelde ongeronde segmente as gerond deur die luisteraars geklassifiseer is.

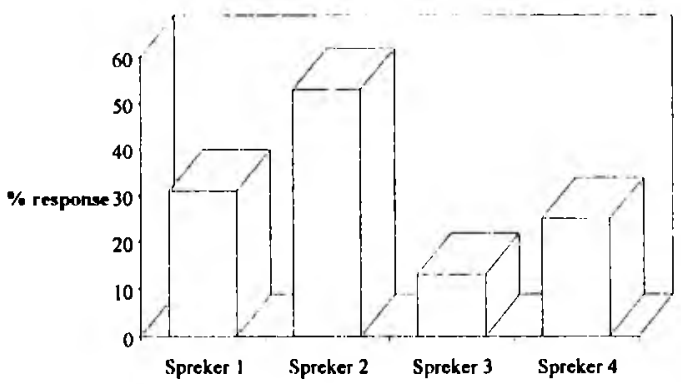

Hier is ' $n$ tendens waar te neem dat die bruin sprekers (Spreker 1 en 2) se bedoelde ongeronde segmente aansienlik meer kere as gerond ervaar word (gem. $42 \%$ teenoor $19 \%$ ). Dit kan egter hoofsaaklik aan Spreker $2(53 \%)$ toegeskryf word. Spreker $4(25 \%)$ rond slegs $6 \%$ minder as Spreker $1(31 \%)$. Spreker 3 is die enigste een wat (met 13\%) ongeveer soos die spreker van Superstandaardafrikaans, na wie hoër op verwys is, ervaar word. Dit is wel duidelik dat hier sprake is van hiperkorreksie van die kant van die sprekers, en veral Spreker 2. 


\subsubsection{Die rol van die bekendheid van woorde}

Ten slotte moet vlugtig gekyk word na die rol wat die bekendheid en/of gebruiksfrekwensie van woorde in 'n eksperiment soos hierdie speel. Hier moet daar wel versigtigheid aan die dag gelê word, omdat daar onsekerheid is oor die verhouding wat daar bestaan tussen bekendheid en gebruiksfrekwensie. 'n Woord soos gees is byvoorbeeld waarskynlik baie bekend maar word nie noodwendig dikwels gebruik nie. Aan die ander kant is die woord geus ongetwyfeld baie onbekend in Afrikaans, en sal dit gevolglik ook selde gebruik word. Frekwensie is dus afhanklik van bekendheid, maar nie (noodwendig) omgekeerd nie. In die volgende twee figure word aangetoon in watter mate die eksperimentele woorde met bedoelde geronde segmente wel as sodanig gedekodeer word of nie. Figuur 10 gee die resultate ten opsigte van al drie die herkenningstake gesamentlik, en Figuur 11 is ' $n$ vergelyking van die persentasie korrekte klassifikasies deur die luisteraars van die woorde met bedoelde geronde segmente in die drie herkenningstake afsonderlik. Hou in gedagte dat die luisteraars in die eerste taak geen skriftelike wenk gehad het om watter woorde dit gegaan het nie, ook nie dat dit spesifiek om gerondheid of ongerondheid gegaan het nie. In die ander twee take was dit wel die geval: Taak 2 was afgesien dáárvan dieselfde as Taak 1, en Taak 3 het pare woorde behels (vgl. weer 4.1.2).

Figuur 10: Vergelyking van die mate waarin die vyf proefwoorde met bedoelde geronde segmente as kern, in al drie herkenningstake gesamentlik, deur die luisteraars geklassifiseer is.

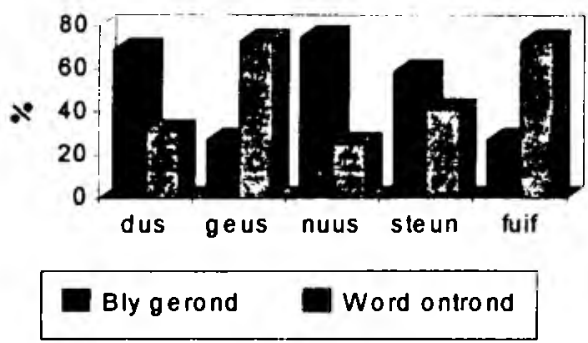

Dit is duidelik dat die twee onbekende woorde, geus en fuif se vokaal/diftong grootliks ontrond word, en dat dit in vergelyking hiermee veel minder gebeur met die vokale van die baie bekende en veelgebruikte woorde dus en nuus, en in 'n mindere mate ook steun. 
Figuur 11: Vergelyking van die mate waarin die luisteraars die bedoelde geronde segmente per afsonderlike herkenningstaak korrek geklassifiseer het

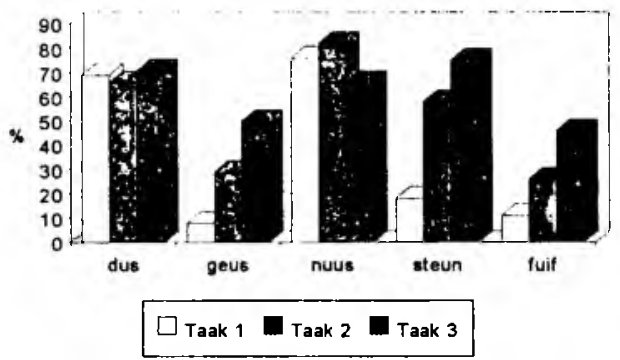

Die onbekende/nie-frekwent gebruikte woorde (geus, fuif) is duidelik baie gevoelig vir konteks of die aard van die taak, teenoor die bekende/frekwent gebruikte woorde (dus en nuus), wat in al drie herkenningstake ongeveer ewe goed presteer. Dit is nie duidelik waarom steun hier anders as in Figuur 10 reageer nie: dáár volg dit ongeveer die teenoorgusivide patroon as geus en fuif, maar hier ongeveer dieselfde.

In Figuur 12 word aangetoon in watter mate die eksperimentele woorde met bedoelde ongeronde segmente wel as sodanig ervaar is of nie, en wel ten opsigte van al drie die herkenningstake gesamentlik. Figuur 13 is 'n vergelyking van die persentasie korrekte klassifikasies deur die luisteraars van die woorde met bedoelde ongeronde segmente in die drie herkenningstake afsonderlik.

Figuur 12: Vergelyking van die mate waarin die vyf proefwoorde met bedoelde ongeronde segmente as $\mathrm{kern}$, in al drie herkenningstake gesamentlik, deur die luisteraars geklassifiseer is.

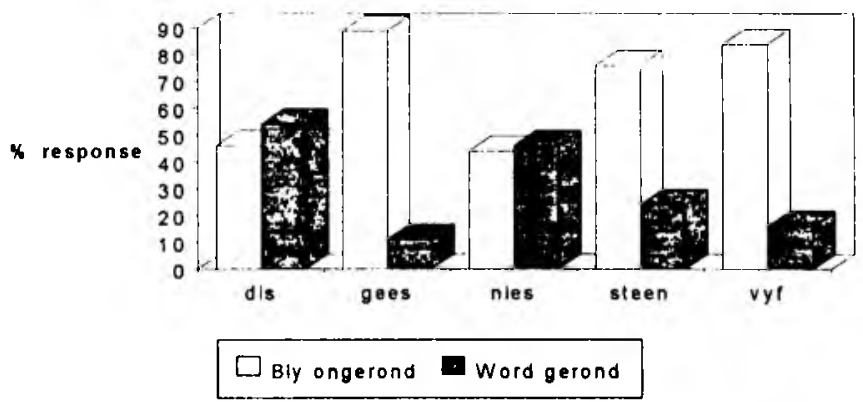


Figuur 13: Vergelyking van die mate waarin die luisteraars die bedoelde ongeronde segmente per afsonderlike herkenningstaak korrek geklassifiseer het

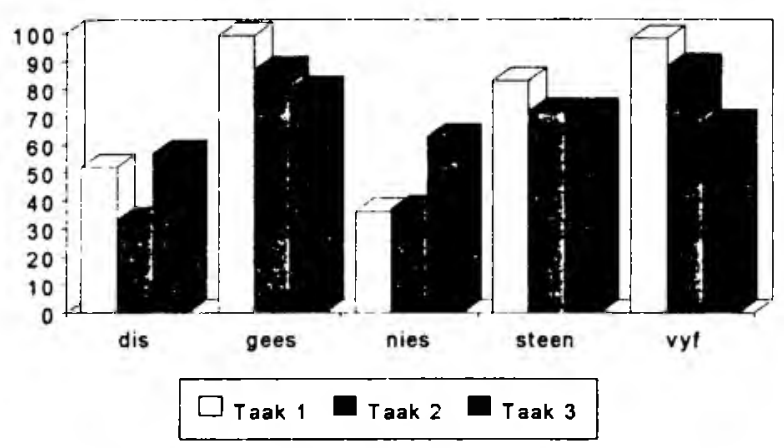

Uit Figuur 12 blyk dit dat daar by die bekende woorde gees, vyf en steen selde geronde segmente waargeneem is, wat eintlik te verwagte is as dit met met Figuur 11 (wat dieselfde ontleding van die woorde met geronde kernsegmente weergee) vergelyk word, waar die teenoorgestelde toestand bestaan. Dit kan ook só gestel word: omdat dit nie by die luisteraar opkom dat daar woorde soos geus en fuif bestaan nie, sal dit ook as gees en vyf gedekodeer word, ongeag die fisiese eienskappe van die woorde. Daarenteen is die vokaalsegmente van dis en nuus ongeveer ewe veel keer as ongerond en gerond geklassifiseer. Dit is eintlik weer eens ' $n$ bevestiging vir die verklaring hierbo: dit is in albei die gevalle (naamlik van sowel dis en nies as dus en nuus) 'n duidelike teken van die onstabiele toestand wat daar in Afrikaans ten opsigte van die gerond-ongeronde opposisie bestaan. Die luisteraars klassifiseer die bekende woorde blykbaar eerder op grond van wat hulle verwag (in hierdie geval eerder $d u s$ i.p.v. dis, wat óf ' $n$ woord is wat selde gebruik word (in die sin van 'n ete) of 'n saamgestelde woord (uit dit $i s)$ ) as wat hulle werklik hoor, en die verwagting word beinvloed deur gebruiksfrekwensie en / of bekendheid (kyk verder die bespreking in 6).

'n Vergelyking tussen Figuur 13 en Figuur 11 (waarin die herkenningstake afsonderlik ontleed is) openbaar wat die vreemde woorde (geus en fulf en hulle maats gees en $v y$ ) betref ' $n$ omgekeerde situasie. Waar die geronde segmente progressief per taak beter herken word, word die ongerondes swakker herken. Wat laasgenoemde betref, is dit weer eens duidelik dat hierdie herkenning gepaard gaan met verwagtinge: in Taak 1, waar daar geen wenk is wat die verwagting na 
die onbekende en dus onverwagte woorde kan stuur nie, word daar telkens gerapporteer dat die bekende woorde (gees vir geus, en vyf vir fuif) gehoor is.

\section{Bespreking}

Die hoofdoel van hierdie ondersoek was om te probeer vasstel of die opposisie tussen die abnormale (geronde) voorvokale en diftong, en hulle ongeronde teëhangers in die uitspraak van die proefpersone, verteenwoordigend van 'moderne' Noordwesafrikaans nog onderliggend aanwesig is. Daarvoor is ' $n$ produksie- en 'n persepsietoets gedoen. 'n Sekondêre doelstelling was om die algemene bewering te toets dat daar wel sprake is van volledige ontronding in die geval van die uitspraak van (minstens sommige) bruin sprekers van Afrikaans. Die teoretiese implikasies van die bevindinge moet ook uitgewys word.

Die produksiegegewens (in terme van segmentlengtes), en wel van al drie die herkenningstake gesamentlik, toon dat daar weliswaar 'n klein verskilletjie is tussen die geronde en die ongeronde groepe segmente $(101 \mathrm{~ms}$ teenoor $92 \mathrm{~ms}$, of $10 \%)$, maar die verskil is nie statisties beduidend nie $(p=0,07)$. Op grond hiervan kan gesê word dat, bloot statisties gesproke, die opposisie tussen die twee groepe dus opgehef is. Die effek van dié onbeduidende verskil in dekoderingsaksies van taalgebruikers moet wel ook ondersoek word.

Die vraag oor hoe die luisteraar hierdie produksies ervaar, met name of hulle die verskil kan hoor, het dus vervolgens aan die orde gekom. Dit is naamlik glad nie 'n uitgemaakte saak dat die temporele eienskappe van hierdie klanke die enigste relevantes is nie. Dit is baie moontlik dat daar wel sodanige spektrale verskille bestaan wat dit vir die dekodeerder moontlik maak om tog die bedoeling van die spreker te bepaal selfs al is daar geen temporele verskille aanwesig nie.

Wat die twee groepe sprekers betref, maak die bruin spreker wat segmentlengtes betref geen onderskeid tussen die twee groepe klanke wanneer al drie die herkenningstake gesamentlik geneem word nie $(p=0,99)$, maar die wit spreker wel ( $p=0,01$, of 'n verskil van $18 \%$ ). Maar selfs die laasgenoemde spreker het geen beduidende verskil gemaak in die eerste leestaak nie, waarin die betrokke woorde as 't ware 'weggesteek' is (vgl. Fig. 2). Dit klop met die uitspraak van CharlesLuce (1993), wat ten opsigte van die opposisie tussen stemhebbende en stemlose eindeksplosiewe in Katalaans bevind het dat dit wel opgehef word in kontekste waarin die betekenis duidelik is. 'n Diskriminantanalise het hierdie verskille tussen die twee groepe sprekers bevestig (vgl. Fig. 4).

Die persepsietoetse het oor die algemeen uitgewys dat 'n spreker van Superstandaardafrikaans die onderskeid tussen die twee groepe segmente nog sodanig handliaaf dat die luisteraars in 'n persepsietoets slegs geringe probleme ondervind om sy bedoelde uitspraak korrek te bepaal (slegs $5 \%$ foute is gemaak). Dit is 
egter te betwyfel of hierdie resultate 'n getroue weerspieëling is van selfs Superstandaardafrikaans soos dit onder nie-eksperimentele omstandighede, met name in informele styl gepraat word. Die waarneming van alledaagse gesproke Afrikaans dui op ' $n$ grootskeepse ontronding (en, anders as in die geval van hierdie eksperiment, seldsame hiperkorrekte ronding). As anekdotiese voorbeeld kan 'n radiopreek oor Afrikaans Stereo (prof. C. Kellerman, 12 Desember 1993) genoem word. Die taalgebruik daarvan moet ongetwyfeld as baie formeel en dié van minstens 'n standaardspreker geklassifiseer word. En tog was daar selde, selfs in die naam Jesus Christus, sprake van geronde abnormale voorvokale. Hierdie opmerking geld nog meer die algemene omgangstaal.

In die geval van die hoofeksperiment met die vier jong sprekers blyk 'n sterk tendens in die rigting van 'n opheffing van die opposisie, maar of daar (reeds) sprake is van die algemene of totale neutralisering van die opposisie tussen die twee groepe segmente is te betwyfel. Dit het bowendien geblyk dat daar ' $n$ aantal faktore is wat 'n rol speel by die uitspraak en/of persepsie daarvan. Die algemene indruk wat gekry word, is dat daar op groot skaal ontrond word, maar dat daar ook gerond word waar dit nie die bedoeling is nie. Dit is moontlik in sommige gevalle aan die formele aard van die leesopdrag toe te skryf, veral in die geval van die pare, waar die indruk soms gekry word dat sommige van die lesers verward raak weens die snelle opeenvolging van geronde en ongeronde klanke. Afgesien van hierdie verklaring bly die indruk egter sterk dat die vokaal-/diftongsisteem van Afrikaans sover dit hierdie aspek aangaan in 'n redelik onstabiele toestand verkeer. Luisteraars vind dit, altans sonder die hulp van konteks, soos in hierdie eksperiment, op groot skaal moeilik om die sprekers se bedoeling ten opsigte van sowel gerondheid as ongerondheid vas te stel. Daar word verskillende tipes foute gemaak: bedoelde geronde segmente word as ongerond ervaar, maar ongerondes word ook as gerond geklassifiseer. Laasgenoemde klassifikasie kan waarskynlik enersyds toegeskryf word aan hiperkorrekte ronding aan die kant van die sprekers, maar andersyds ook aan verwagtinge, wat sterk gekoppel is aan die bekendheid van die betrokke woorde. Dit het naamlik geblyk dat die aard van die stimuluswoorde, asook die aard van die herkenningstaak 'n beduidende rol gespeel het, en dat hierdie twee faktore in interaksie met mekaar is. Soos uit Figuur 11 blyk, word die minste segmente wat bedoel was om gerond uitgespreek te word in onbekende woorde (soos geus en fuif) in die eerste herkenningstaak korrek geklassifiseer, en die meeste in die (laaste) paretaak. Dit geld egter nie vir die frekwent gebruikte woorde (soos dus en nuus) nie. Die gelyke mate waarin hulle in al drie herkenningstake korrek geklassifiseer is, dui daarop dat woorde wat baie bekend is, ongevoelig is vir die aard van die taak. Dit is verder ook moontlik dat die feit dat die taalgebruiker bewus is daarvan dat veelgebruikte woorde soos dus en nuus ook ongeronde maats (dis en nies) het, 'n invloed kan hê op die wyse waarop hy/sy as hoorder hierdie woorde sal dekodeer. Dit is ook 
aanvaarbaar dat 'n woord soos gebruik baie waarskynlik as gebruik (met geronde diftong) gedekodeer sal word, selfs al word dit fisies met 'n ontronde diftong uitgespreek, bloot omdat dit nie 'n teëhanger * gebryk/gebreik het nie, en natuurlik omdat die dekodeerder bewus is van die spellingvorm. Die struktuur/inhoud van die leksikon van 'n betrokke taal plus die spelling van die betrokke woorde sou dus ook meespeel in die wyse waarop woorde gedekodeer/geklassifiseer word. Dit moet egter nog empiries geverifieer word. Die feit is egter dat dis en nies in hierdie eksperiment (vgl. Fig. 12) meer dikwels foutiewelik geklassifiseer is asof hulle vokale gerond sou wees (albei word slegs in ongeveer $45 \%$ van alle gevalle korrek as dis en nies geidentifiseer).

Om saam te vat: die studie het, selfs onder die hiperformele omstandighede van 'n eksperiment van hierdie aard, altans indien slegs die temporele eienskappe van vokaliese segmente in ag geneem word, aangetoon dat daar op groot skaal ontrond word in Afrikaans. Indien die opvoedingspeil van die sprekers en die aard van die eksperiment in ag geneem word, sou 'n mens kon sê dat dit hier om (minstens) ' $n$ standaarduitspraak van Afrikaans gaan. In soverre hierdie aanname juis is, is die uitspraak van De Villiers en Ponelis (1987:102-3) dat die afwesigheid van ontronding "merkers van standaarduitspraak" is, dan natuurlik ónjuis: hier is beslis geen sprake van ' $n$ afwesigheid van ontronding nie. Hulle uitspraak kan, met verwysing na die subeksperiment, hoogstens op die sogenaamde Superstandaardafrikaans van toepassing gemaak word. Dit kom seker neer op die moeilike kwessie van hoe Standaardafrikaans gedefinieer moet word. De Villiers en Ponelis is natuurlik korrek indien hulle die uitspraak van wat hier Superstandaardafrikaans genoem word as gewone Standaardafrikaans tipeer. Maar dan moet hulle die Afrikaans van die proefpersone, wat hier Standaardafrikaans genoem word, iets anders noem. Miskien moderne Standaardafrikaans?

Die proses van ontronding is, soos uitgewys, in die uitspraak van hierdie sprekers, al ver gevorder, maar in die lig van die persepsietoets nog nie só ver dat die geronde abnormale voorvokale en diftong uit die onderliggende fonologiese sisteem van Afrikaans verwyder kan word nie. Aan die ander kant toon die moedertaaldekodeerder van Afrikaans in die persepsie-eksperiment, waarin die meeste van die onnatuurlikheid en hiperformaliteit afwesig is, tog wel baie duidelike tekens dat dié sisteem op sy minste in 'n toestand van verandering, en beweging in die rigting van totale ontronding verkeer. Bloot na die huidige resultate geoordeel, is hier ook (nog) nie sprake van 'n volledige neutralisasie van die opposisie tussen die abnormale geronde vokale/diftonge en hulle geronde teëhangers nie. Dit het in hierdie eksperiment baie duidelik geblyk dat verskeie faktore, waaronder die mate van bekendheid van die stimuluswoorde en die aard van die leesen die luistertaak deeglik in ag gehou moet word by eksperimente van hierdie aard. Dit is volkome denkbaar dat daar in 'n soortgelyke eksperiment wel ' $n$ absolute neutralisasie gevind sal word indien daar slegs van baie bekende woorde 
gebruik gemaak word, en indien dié woorde slegs in sinskonteks voorkom. Dit sou nóg beter wees indien die woorde sonder verwysing na 'n geskrewe teks op 'n meer natuurlike wyse ontlok kan word.

Wat die verskil tussen wit en bruin sprekers van Afrikaans betref, is daar duidelike tekens van verskille, met die bruin sprekers ' $n$ stap vóór die wit sprekers op pad na 'n nuwe vokaal-/diftongsisteem. Indien die proefpersone van hierdie eksperiment as verteenwoordigend van die sprekers van (Standaard)afrikaans oor die algemeen geneem sou word (wat uit die aard van die saak baie versigtig gedoen moet word, indien wel), sou gekonkludeer kon word dat die opposisie tussen die Afrikaanse abnormale geronde voorvokale (-diftong) op die oomblik in 'n baie onstabiele toestand is, minstens in sommige variëteite. Noukeurige (informele) waarneming van die spraak van 'n wye verskeidenheid Afrikaanssprekers oor 'n lang tydperk ondersteun hierdie konklusie.

\section{Verwysings}

Charles-Luce, J. 1985. Word-Final Devoicing in German: Effects of Phonetic and Sentential Contexts. Journal of Phonetics, 13:309-324.

Charles-Luce, J. 1993. The Effects of Semantic Context on Voicing Neutralization Phonetica, 50:28-43

Charles-Luce, J. \& Dinnsen, D.A. 1987. A Reanalysis of Catalan Devoicing Journal of Phonetics, 15:187-190.

De Villiers, M \& Ponelis, F.A. 1987. Afrikaanse klankleer. Kaapstad : Tafelberg

De Wet, AS. 1993. Swartafrikaans as niestandaardvariëteit van Afrikaans. Suid-Afrikaanse Tydskrf vir Taalkunde. Supplememt 18.

Dinnsen, D.A. \& Charles-Luce, J. 1984. Phonological Neutralization, Phonetic Implementation and Individual Differences. Journal of Phonetics, 12:49-60

Eefting, W. 1991. The Effect of "Information Value" and "Accentuation" on the Duration of Dutch Words, Syllables and Segments. Journal of the Acoustical Society of America, $89(1): 412-24$

Fourakis, M. \& Iverson, G.K 1984. On the "Incomplete Neutralization" of German Final Obstruents Phonelica, 41:140-149.

Jassem, W. \& Richter, L. 1989. Neutralization of Voicing in Polish Obstruents Journal of Phonetics, 17:317-325.

Klopper, R.M. 1983. Die sosiale stratifisering van Kaapse Afrikaans. In: Claassen, G.N \& Van Rensburg, M C.J. (reds.). Taalverskeidenheid: 'n Blik op die spektrum van taalvariasie in Afrikaans. Pretoria : Academica pp. 80-100

Kotzé, E.F 1984. Afrikaans in die Maleierbuurt: 'n Diachroniese perspektief. Tydskrıf vir Geesteswerenskappe, 24: 41-73.

Links, Tony. 1989. So praat ons Namakwalanders. Kaapstad : Tafelberg.

Meiring, B A. \& Retief, R. 1991. Funksionele Afrikaans. Pretoria : Academica.

O'Shaughnessy, D 1981. A Study of French Vowel and Consonant Durations. Journal of Phonetics, 9:385-406.

Ponelis, F. A. 1990/1 Historiese klankleer van Afrikaans. Annale van die Universiteit van Stellenbosch. 
Port, R. \& Crawford, P. 1989. Incomplete Neutralization and Pragmatics in German. Journal of Phonetics, 17:257-282

Port, R., Mitleb, F \& O'Dell, M 1981. Neutralizing of Obstruent Voicing in German is Incomplete. .Journal of the Acoustical Society of America, 70 (suppl. 1): 13.

Port, R. \& O'Dell, M. 1985. Neutralization of Syllable-Final Voicing in German. Journal of Phonetics, 13:455-471.

Raubenheimer, H. 1994. Enkele aspekte van die temporele eienskappe van lang vokale en diftonge in Afrikaans. Potchefstroom : PU vir CHO. (M.A.-verhandeling.)

Repp, B.H. \& Williams, D.R. 1985. Influence of Following Context on Perception of the Voiced-Voiceless Distinction in Syllable-Final Stop Consonants. Journal of the Acoustical Society of America, 78(2): 445-457.

Slowaiczek, L.M. \& Dinnsen, D.A 1985 On the Neutralizing Status of Polish Word-final Devoicing. Journal of Phonetics, 17:205-212

Van Bree, C. 1987. Historische grammatika van het Nederlands. Dordrecht : Foris Publications

Van Wyk, E.B. 1977. Praktiese fonetiek vir taalstudente. Durban : Butterworths

Van Wyk, E B. 1983 Gepidgineerde Afrikaans. In: Claassen, G.N. \& Van Rensburg, M.C.J. (reds.). Taalverskeidenheid: 'n Blik op die spektrum van taalvariasie in Afrikaans. Pretoria: Academica. pp. 162-170.

Wissing, D P 1982. Algemene en Afrikaanse generatiewe fonologie. Johannesburg : MacMillan.

Wissing, D P \& Van Rooy, A.J. 1992. Onvolledige neutralisasie: die ontstemmingsreël in Afrikaans. South African Journal of Lingitistics, Supplement 13:135-144.

\section{Potchefstroomse Universiteit vir CHO}


